\title{
NOTE
}

\section{Life cycle and reproduction of the dinoflagellate Dinophysis norvegica}

\author{
D. V. Subba Rao* \\ Habitat Ecology Division, Department of Fisheries and Oceans, Bedford Institute of Oceanography, PO Box 1006 , \\ Dartmouth, Nova Scotia, Canada B2Y 4A2
}

\begin{abstract}
Developmental stages resulting from inoculation of isolates and concentrates of toxigenic Dinophysis norvegica are described. Similarities exist in the developmental stages of $D$. acuminata, $D$. acuta, $D$. pavillardi and $D$. norvegica. Physical oceanographic mechanisms explain only the distribution of the cells in a red tide resulting from Dinophysis, but not the biomass. However, sexual reproduction as a prerequisite can account for the abundance of cells and therefore the formation of the red tide.
\end{abstract}

KEY WORDS: Dinophysis $\cdot$ Life cycle $\cdot$ Toxigenic blooms

A bloom of Dinophysis norvegica, a dinoflagellate associated with diarrhetic shellfish poisoning, was reported by Subba Rao et al. (1993) in Bedford Basin, Nova Scotia, Canada. Although the actual bloom lasted from 20 July to 3 August 1990 (with an abun-

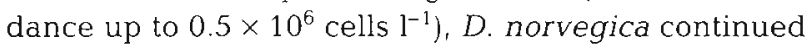
to be present at a depth of about $10 \mathrm{~m}$ until 20 September 1990. All trials to culture this dinoflagellate were at best qualified successes. Some isolates kept in dilute media divided thrice over a $12 \mathrm{wk}$ period while a few yielded developmental stages. In this note, I record additional light microscope observations on developmental stages resulting from inoculation of isolates and concentrates of toxigenic $D$. norvegica. This account will add to the observations on $D$. acuminata, $D$. acuta and D. pavillardi made by Berland et al. (1995 - this issue).

In this bloom there were 2 size classes of Dinophysis cells, the large $\left(65\right.$ to $73 \mu \mathrm{m}$ long $\times 45$ to $50 \mu \mathrm{m}$ broad $_{i}$ Figs. $1 \& 2$ ) and the small ( 45 to $50 \times 30$ to $50 \mu \mathrm{m}$ ), consistent with observations on Dinophysis species (Berland et al. 1995). The large cells had heavier thecae (Figs. 3 \& 4), with dense pigmentation - a mix of yellow-brown and red - than the smaller size class which had normal cell wall and light greeenish-yellow

•E-mail: durvas@bionet.bio.dfo.ca pigmentation. The larger cells had a rugged thick cell wall and occasionally had 1 large densely packed body (Fig. 5), corresponding to the shape of the main cell. Because of the thicker cell wall, heavy pigmentation and loss of lists (Figs. $4 \& 5$ ) these could be cysts similar to those described for D. acuta, D. tripos, and $D$. digensis (Mackenzie 1992, Moita \& Sampayo 1993). A few large cells (Figs. $7 \& 8$ ) contained 2 round or oval dark bodies (15 to $20 \mu \mathrm{m}$ diameter) with a distinct wall, comparable to 'cyst-like bodies' (Berland et al. 1995) while a few others (Fig. 6) contained up to 16 small ( 4 to $6 \mu \mathrm{m}$ ) bodies.

Two kinds of couplets (Figs. 1 \& 2) were observed: (1) large (>62 $\mu \mathrm{m}$ ) identical cells mainly joined at the ventral edge and (2) dissimilar cells (22 and $25 \mu \mathrm{m}$ broad and $62 \mu \mathrm{m}$ long) joined in the sulcate regions similar to that for Dinophysis acuta and D. dens (Mackenzie 1992). In the couplets, the cleavage in the joint varied from a slight notch to a deep furrow. One of the couplets had a dark conspicuous nucleus. Couplets constituted $<1 \%$ of the total Dinophysis population. Subsequent to isolation couplets swam for 2 to $3 \mathrm{~d}$ and the cells separated. Whether there was nuclear fusion between these couplets could not be determined in these trials. The couplets fluoresced bright red when excited with blue (420 to $490 \mathrm{~nm}$ ) light.

Attempted growth trials. The culture media were based on enrichment or freshly collected bloom water filtered through glass fibre filters $(0.7 \mu \mathrm{m})$. Nuclepore $(0.4 \mu \mathrm{m})$ filtered bloom water was used to maintain Dinophysis spp. as well as a variety of media: $\mathrm{K} 1 / 10$ (Keller et al. 1987), F (Guillard \& Ryther 1962), FE (Subba Rao et al. 1988), full strength to $1 / 10$ enrichment, with and without additional silica or copper or chelator. Media were steam-sterilized or filter-sterilized. Dinophysis were isolated with a Pasteur pipet with an orifice 5 to 6 times larger than the cells. Cells were washed gently with sterile media several times under a microsope. This treatment did not adversely 

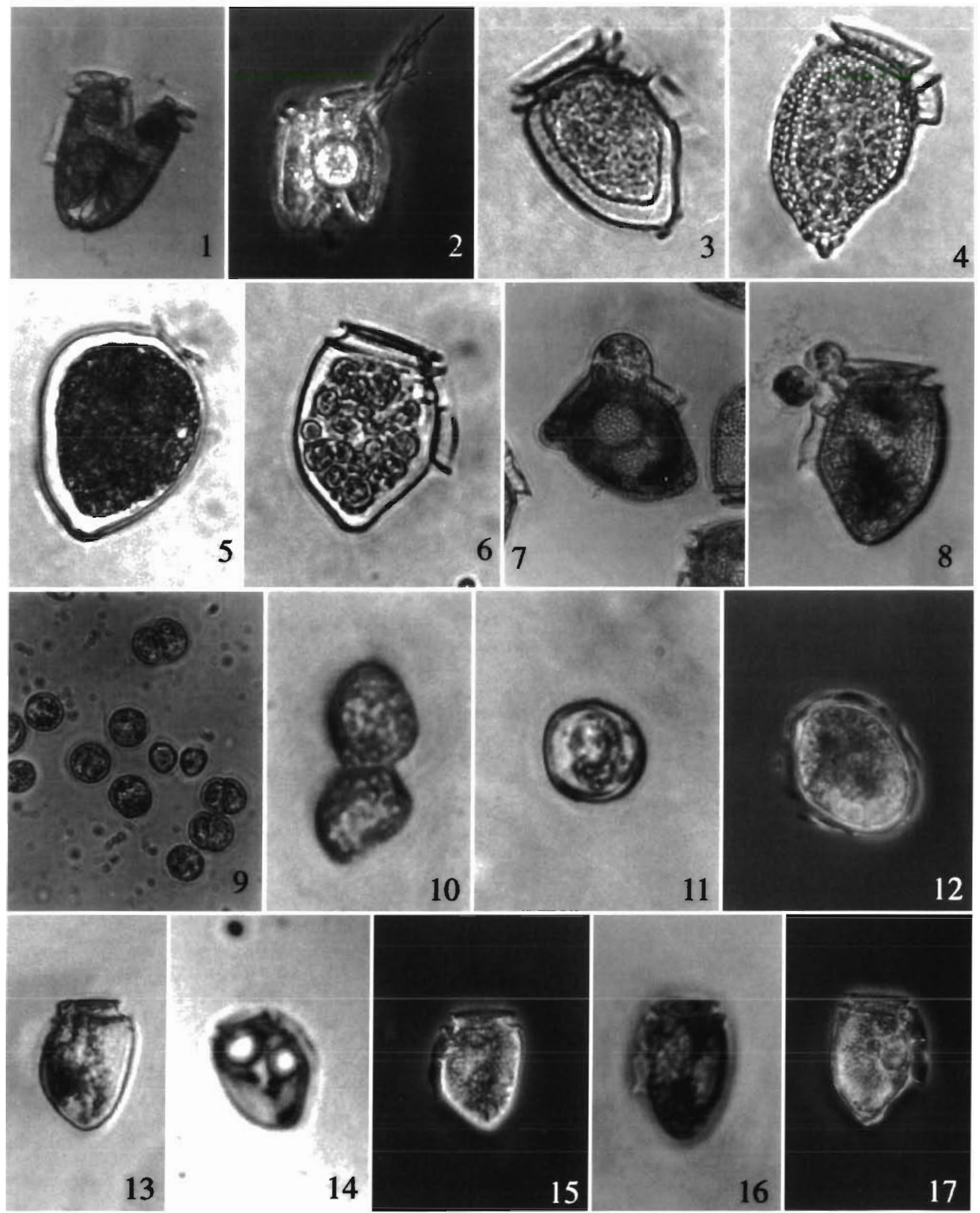

Figs. 1 to 17 Dinophysis spp. Figs. 1 \& 2. Couplets of D. norvegica. Figs. 3 to 5 . Cyst formation. Fig. 6 . Cells with small (4 to $6 \mu$ m bodies. Figs. $7 \& 8$. Release of larger $(-15 \mu \mathrm{m})$ bodies. Figs. $9 \& 10$. Pairing of gametes $(2$ to $3 \mu \mathrm{m})$. Figs. $11 \& 12$. Zygote formation. Figs. 13 to 17 . Development of a small Dinophysis 
affect the swimming behaviour of cells. Individual cells were transferred to multiple-well tissue culture plates with a low evaporation lid, each well with $2 \mathrm{ml}$ sterile media. Also, cells were drawn into non-heparinized micro haematocrit tubes and the ends were sealed with paraffin wax. Samples were incubated at $10^{\circ} \mathrm{C}, 16 \mathrm{~h}$ light $\left(120 \mu \mathrm{mol} \mathrm{m} \mathrm{m}^{-2} \mathrm{~s}^{-1}\right)+8 \mathrm{~h}$ dark; development was followed by microscopic examinations.

By the third day, some of the cells with dense cytoplasm released 2 to $4(\sim 15 \mu \mathrm{m})$ bodies from the flagella pore (Fig. 8). These could have been packets of gametes. As a result of this clearance cells appeared to be worn out, and ultimately they died. Similar clearance followed by death was also observed in a flask inoculated with 54 Dinophysis cells. This is consistent with a Maupasian life cycle of certain protists where gamete production culminates in death (see Bell 1988). A large number of round bodies ( 2 to $5 \mu \mathrm{m}$ ) ensued (Fig. 9) and must have originated either from the larger $(\sim 15 \mu \mathrm{m})$ or smaller ( 4 to $6 \mu \mathrm{m}$ ) bodies; these formed a string of mucus along the wall of the culture well. At times two of these bodies, not necessarily of the same size and shape (Figs. $9 \& 10$ ), paired and rotated clockwise. There was a repeated attraction of a putative gamete towards another, common to many eukaryotic organisms (Pagel 1993). The presence of small empty casts $(5 \mu \mathrm{m})$ and formation of larger bodies ( 7 to $13 \mu \mathrm{m}$ ) also suggests that they may have been the result of fusion of gametes with smaller bodies. Pear-shaped cells (Figs. $11 \& 12$ ), with a size range of $10 \times 20 \mu \mathrm{m}$ and $25 \times 40 \mu \mathrm{m}$, initially non-motile, were observed and soon developed a frilled wall (Fig. 12) and 2 flagella. These are probably the planozygotes reported in other Dinophysis species (Berland et al. 1995 and references therein). The larger cells exhibited tumbling and undulating movements, typical of Dinophysiales. They were faint yellow and fluoresced red when excited by blue (420 to $490 \mathrm{~nm}$ ) light. Progressively, cells with a cingulum (girdle, Fig. 13), an anterior rib and sulcate lists were noticed (Figs. 14, 15 \& 16). The cells had a thin wall and developed a more yellowish-green colour and continued to fluoresce red. The smallest Dinophysis cell was $45 \times 28 \mu \mathrm{m}$ (Fig. 17).

From these observations on the developmental stages in a reconstructed life cycle for Dinophysis norvegicus, 5 important points emerge. (1) Despite serious gaps in the information on growth and development, the existence is shown of several similarities in the development stages of $D$. acuminata, $D$. acuta, D. pavillardi and D. norvegica. (2) Trying to culture 'gravid' Dinophysis could explain why cultures could not be successfully established. (3) Not all blooms of potentially toxic Dinophysis are actually toxic. Toxicity of a bloom might be dependent upon the stage of the life cycle, as has been observed for Pseudonitzschia pungens f. multiseries (Subba Rao et al. 1991). (4) Although the problem of reproduction has not been resolved, the indispensibility of culture studies of Dinophysis that hold crucial clues is emphasized. (5) The extremely slow vegetative division rate of $\sim 1$ division per month alone cannot explain the formation of red tides by Dinophysis species. As an exponential increase of the population is a prerequisite, any model to explain the formation of a red tide resulting from Dinophysis should include the role of sexual reproduction. Then only physical oceanographic mechanisms would be needed to explain the accumulation and an outbreak of toxigenic blooms. These are clearly areas for further research.

Acknowledgements. My grateful thanks are due to my colleagues Drs J. E. Stewart, D. C. Gordon, T. Platt, Y. Pan and $\mathrm{Mr}$ G. D. Wohlgeschaffen for reviewing the manuscript. Special thanks go to $\mathrm{Mr} \mathrm{H}$. Wiele for his expertise, patience and skilful assistance with the microphotography.

\section{LITERATURE CITED}

Bell G (1988) Sex and death in protozoa, the history of an obsession. Cambridge University Press, Cambridge

Berland BR, Maestrini SY, Grzebyk D (1995) Observations on possible life cycle stages of the dinoflagellates Dinophysis cf. acuminata, Dinophysis acuta and Dinophysis pavillardi. Aquat microb Ecol 9:183-189

Guillard RRL, Ryther JH (1962) Studies of marine planktonic diatoms I. Cyclotella nana Hustedt and Detonula confervaceae (Cleve) Gran. Can J Microbiol 8:229-239

Keller MD, Selvin RC, Claus W, Guillard RRL (1987) Media for the culture of oceanic ultraphytoplankton. J Phycol 23: $633-638$

Moita MT, Sampayo MA De M (1993) Are there cysts in the genus Dinophysis? In: Smayda TJ, Shimuzu Y (eds) Toxic phytoplankton blooms in the sea. Elsevier Sci Pub. Amsterdam, p 153-157

Pagel M (1993) Honest signalling among gametes. Nature 363:539-541

Subba Rao DV, Quilliam MA, Pocklington R (1988) Domoic acid-aneurotoxic amino acid produced by marine diatom Nitzschia pungens in culture. Can J Fish Aquat Sci 45:2076-2079

Subba Rao DV, Partensky F, Wohlgeschaffen G, Li WKW (1991) Flow cytometry and microscopy of gametogenesis in Nitzschia pungens, a toxic, bloom-forming, marine diatom. J Phycol 27:21-26

Subba Rao DV, Pan Y, Zitko V. Bugden G, Mackeigan K (1993) Diarrhetic shellfish poisoning (DSP) associated with a subsurface bloom of Dinophysis norvegica in Bedford Basin, eastern Canada. Mar Ecol Prog Ser 97:117-126 